\title{
Further Notes on Transfer Tax Rates
}

\author{
Joseph Isenbergh $\dagger$
}

Professor Sims and I have proposed measures addressed to the difference in the tax base for lifetime gifts and transfers at death. ${ }^{1}$ What follows here, as a postscript, is a brief evaluation of the stakes involved in the choice between our two approaches. These notes assume familiarity with the underlying problem, which is expounded at some length in the two preceding articles.

What the tax base difference boils down to is that lifetime gifts are taxed at lower effective rates, despite the application of a single schedule of rates. ${ }^{2}$ Thus a tax of $50 \%$ on the present gift tax base (the net amount received by the donee) is equivalent to a tax of $331 / 3 \%$ on the full amount (gift plus tax) actually given up by the donor (the amount which would be included in the taxable estate at death under present law). As part of a set of proposals to simplify the transfer tax rules, I have suggested curtailing the discrepancy between the gift and estate tax bases by adding the amount of gift taxes paid during life to the taxable estate at death. ${ }^{3}$ Professor Sims, going farther, would essentially equalize the gift tax base and the estate tax base by increasing gift tax rates during life to levels that are equivalent in effect to the full "grossup" of the gift tax base by the amount of gift tax paid." How to choose between these two approaches?

When tax is imposed on a lifetime gift under present law, the amount paid is less than the amount that would be paid if the tax were imposed instead on the estate tax base. Assuming for simplicity a $50 \%$ rate of tax, a gift of $\$ 100$ will attract a tax of $\$ 50$. By contrast, a $50 \%$ rate applied to the full $\$ 150$ given up by the donor-the estate tax base-would yield a tax of $\$ 75$. The difference

$\dagger$ Professor of Law, University of Chicago. Research for this article was supported by a grant from the Russell Baker Scholars Fund.

${ }^{1}$ See Isenbergh, Simplifying Retained Life Interests, Revocable Transfers, and the Marital Deduction, 51 U. CHr. L. Rev. 1, 2-16 (1984); Sims, Timing Under a Unified Wealth Transfer Tax, 51 U. CHI. L. REv. 34, 52-69 (1984).

2 Under present law, the gift tax applies to the net amount of lifetime gifts after tax, see I.R.C. $\S 2503$ (a) (1982), while the estate tax base includes the tax itself, see I.R.C. $\S$ 2053(c)(1)(B) (1982). Professor Sims calls these tax bases "tax exclusive" and "tax inclusive" respectively. See Sims, supra note 1 , at 40.

3 See Isenbergh, supra note 1 , at 14-15.

- See Sims, supra note 1, at 56-69. 
in tax base, then, yields a $\$ 25$ difference in tax. This difference can be regarded as a tax "saving," but that word ought to remain in quotation marks until we are certain that the higher tax of $\$ 75$ represents an appropriate norm against which to measure the tax paid during life.

At all events, this $\$ 25$ can be regarded as a tax rate advantage of lifetime gifts. Like any present value, the $\$ 25$ can be divided into two components: the present value of an interest to be received at a point in the future and the value of an income stream between now and that future point. Thus, in the hands of someone with a life expectancy of 5 years, a $\$ 25$ tax saving today can be expressed, if we assume a discount rate of $10 \%$, as the sum of the present value of $\$ 25$ in 5 years $(\$ 15.50)$ and the value of the income from $\$ 25$ for 5 years $(\$ 2.50$ a year for 5 years-worth $\$ 9.50$ today).

This dissection of the $\$ 25$ lays bare the difference between my proposal and Professor Sims's for modifying transfer tax rates. Professor Sims's proposal, by grossing up the gift tax base in full during life, adds the entire $\$ 25$ to the tax cost of the lifetime gift. The proposal I make-restoring gift taxes paid during life to the taxable estate at death-adds only a component of this $\$ 25$ to the present tax cost. Specifically, it increases the tax cost of the lifetime gift only by the present value of the $\$ 25$ tax payable at death (50\% of the $\$ 50$ gift tax added to the taxable estate at death). ${ }^{5}$ Therefore, a tax "saving" for lifetime gifts remains under my proposal, as compared to that of Professor Sims, equal to the time value of the $\$ 25$ amount between the time of the gift and the date of death.

Assuming a 5-year life expectancy, the difference in present tax cost between the two methods-the time value component of $\$ 9.50$ (discounted at $10 \%$ ) -is less than the present value component ( $\$ 15.50)$ of the total $\$ 25$ at issue. If, however, we assume a gift made 14 years before death, the time value component (\$18.75) is significantly larger than the present value component (\$6.25). As compared to Professor Sims's, therefore, my proposal results in a milder counterbalance to the tax base differences between lifetime transfers and transfers at death. If a long enough time elapses between a gift and death, the tax cost of lifetime gifts under my approach might not be much greater than under current law.

Professor Sims's solution appears more rigorously to equalize

- If the gift tax paid during life $(\$ 50)$ is added to the estate at death, it will attract a tax of $\$ 25$ at that time given a $50 \%$ tax rate. 
the effective tax rates of lifetime transfers and transfers at death. By the same token, it appears more "neutral" in its effect on the choice between lifetime transfers and transfers at death. This difference perhaps reflects our different aims. I set out to simplify transfer taxation. In so doing, I hoped to find a system that did not significantly favor lifetime gifts compared to the present regime. Professor Sims sets out to increase the neutrality of the rate structure as his central objective. Doubtless his proposal comes closer to this end than mine.

Neither proposal, however, achieves in my view the nec plus ultra of neutrality in transfer tax rates. Neutrality is to some extent in the eye of the beholder. It depends on what one is comparing with what. Professor Sims's proposal imposes a tax on lifetime transfers in precisely the same amount as the tax imposed at death. While this approach equalizes the rates arithmetically, I believe that in practical effect it burdens lifetime transfers to an extent that makes them appreciably more costly than transfers at death. The added cost results from the relatively high value people attach (as they should) to the deferral of taxation.

When a taxable transfer is made during life, a value must be assigned to it. If the transfer is of a future interest, its present value must be predicated on a discount rate, which in turn reflects an anticipated rate of return available on invested assets. Another element in evaluating a lifetime transfer entailing a present tax is the implicit rate of return applied to measure the cost of paying a tax that would have been deferred if the transfer had not been made.

I suggest in my article that the discount rate used to value the present cost of a tax paid in the future (in effect, the time value of tax deferral) should probably be greater than the discount rate applied to the amounts of the actual transfers themselves. ${ }^{6}$ Suppose you have $\$ 1000$ and the transfer tax rate is $50 \%$ on a fully inclusive basis. If you make a gift of $\$ 300$ now, you will pay a gift tax of $\$ 300$ and retain $\$ 400$ for yourself. If that amount is enough for you to live on, fine. But if your circumstances change (your other income decreases, or you become very ill, or you remarry) the $\$ 400$ may prove inadequate to your needs. It may turn out that you would rather have retained and consumed more during your lifetime, in which case the aggregate transfer tax would have been less. Now it is too late. You have made the gift and paid the tax in

- See Isenbergh, supra note 1 , at 11-12 \& nn. $41 \& 43$. 
an amount greater than you would have paid if you had consumed more and waited until death to dispose of the balance of your property. Your present choices are either to constrain yourself to a style of life different from the one you would have chosen had you retained more wealth (a course obviously imposing significant imputed costs) or to receive return gifts from your former beneficiaries in an amount necessary to maintain the level of consumption you desire. In the latter event, setting aside its likelihood, the transfer tax system provides no refunds even though the total net transfer to your donees is smaller. For these reasons, you will implicitly (and rationally, I believe) set a high value on the deferral of taxation that results from the passive course of making no lifetime transfers, and you will be reluctant to make lifetime transfers as a result. This analysis explains in part, I think, why lifetime gifts are often not made until people are quite old, despite the apparent tax advantages of making them earlier.

Put more abstractly, it seems to me unlikely as a general proposition that the same discount rate should be applied to the deferral of transfer tax and the valuation of transfers subject to that tax. ${ }^{7}$ A single discount rate, however, is implicit in Professor Sims's proposed system of full gross-up. ${ }^{8}$ The resulting tax base and rate schedule tend somewhat to penalize lifetime transfers. On the other hand, my proposal assigns so high an implicit value to deferral of tax that it may make lifetime tranfers overly attractive.

If, using the tax-exclusive gift tax base of current law, we assume a $50 \%$ tax rate, the owner of $\$ 1000$ whose life expectancy is 7 years can transfer $\$ 666$ today at a present tax cost of $\$ 333$, or wait until death and leave $\$ 2000$ (assuming a rate of return of $10 \%$ ). The tax at death will be $\$ 1000$. The choice in this case is between a tax of $\$ 333$ today or of $\$ 1000$ in 7 years. The discount rate that equalizes these two amounts is roughly $17 \%$, notably higher than the $10 \%$ discount rate applied to the estate itself. The owner will make a present transfer unless the implicit value of tax deferral is

7 An analogous principle is followed in finance theory, which treats cash fiows resulting from anticipated tax savings (in connection with transactions such as leveraged leases) as safer (and therefore to be discounted at a lower rate) than the amounts anticipated from actual business operations. See R. Brealey \& S. Myers, Principles of Corporate Finance 539 (1981) (depreciation tax shields on leveraged lease are safer than other returns because they are independent of business fortunes). If a tax saving is relatively more valuable than other income flows, then conversely, an earlier increase of tax must be relatively more costly than other expenses.

See Sims, supra note 1, at 76, 78-82 (appendix A, stating formulas for discounting value and for gross-up of lifetime gifts). 
greater than $17 \%$.

Under the tax base adjustment proposed in my article, ${ }^{9}$ a present gift of $\$ 572$ can be made at present tax cost of $\$ 286$. The remaining $\$ 142$ will grow to $\$ 284$ in 7 years, which will entail a taxable estate of $\$ 570$ at that time ( $\$ 284$ plus the $\$ 286$ gift tax paid during life) and a transfer tax of $\$ 285$. The choice under my proposal is thus between (1) a tax of $\$ 286$ now plus payment of $\$ 285$ in 7 years, or (2) a tax of $\$ 1000$ in 7 years (if no lifetime transfer is made). The discount rate that equalizes these two tax costs is slightly less than $15 \%$, still significantly higher than the uniform $10 \%$ discount rate implicit in the system of transfer tax rates proposed by Professor Sims. If this $15 \%$ rate remains higher than the discount rate appropriate for valuing deferred taxes, then my proposal will undertax lifetime transfers. By the same token, to the extent that a $10 \%$ rate is lower than the discount rate appropriate for valuing deferred taxes, Professor Sims's proposal will overtax lifetime transfers.

There is a way of bridging the gap between Professor Sims's proposal and my own. It is possible to restore part, but not all, of the time value of deferred taxes to the estate at death. This result could be achieved by adding to the estate the amount of gift taxes paid during life, increased by an interest factor chosen to reflect as accurately as possible the value of tax deferral. The rate used in arriving at this interest factor would be lower than the discount rate used to value transfers, because early payment of tax would otherwise be too costly. If $10 \%$ is used to value the transfers themselves, $71 / 2 \%$ might be used to increase the amount added to the estate at death. Thus in our example, the owner of $\$ 1000$ could make a present gift of $\$ 522$ and pay a present gift tax of $\$ 261$. This would leave $\$ 217$ in the estate, which, at $10 \%$, would grow to roughly $\$ 434$ in 7 years. The gift tax of $\$ 261$ paid during life, with interest compounded at $7 \frac{1}{2} \%$, would itself grow to $\$ 433$. If death arrives on schedule, the total estate of $\$ 867$ will attract a further tax of $\$ 433.50$. The discount rate necessary to equalize the tax cost of the lifetime transfer and the transfer at death is roughly $131 / 3 \% .^{10}$

- See Isenbergh, supra note 1, at 14-15.

10 The higher discount rate applied in valuing present tax costs and the lower interest rate used in adding the time value of the deferred tax are in fact reciprocal factors of the $10 \%$ discount rate used to value transfers ( $1 / 3$ and $3 / 4$ of that rate respectively). A higher discount rate is used to measure the present cost of a deferred tax, because a higher implicit return is assumed from a tax saving than from funds committed to a future interest. By contrast, the interest added to the deferred tax is lower in order to make the earlier pay- 
In effect, the taxpayer has been allowed to borrow part of the transfer tax from the government at a relatively favorable interest rate of $7 \frac{1}{2} \%$. By contrast, Professor Sims's proposal is tantamount to requiring the taxpayer's estate to pay interest on the gift tax at the full $10 \%$ rate.

It may be impossible to know in any given case how much lower the interest factor applied to the tax component should be than the basic discount rate used to value the transfers themselves. That, along with obvious difficulties of administration, may well make it impossible to give practical effect to the system just sketched. I offer it, therefore, not as a concrete proposal, but as an illustration of a rate structure that makes the choice between lifetime transfers and transfers at death as nearly as possible a matter of indifference.

Assuming the choice of rate structures is limited to Professor Sims's or to the one suggested in my article, I find either acceptable. In the end, the choice would depend on whether one wanted to bear relatively more heavily or lightly on lifetime transfers. One thing is certain, however. If Professor Sims's rate structure were adopted, the case for sweeping away the cobweb of special rules governing retained life interests, revocable transfers, and the marital deduction-all of which serve to some extent to undercut possible tax advantages from lifetime transfers-would be even stronger. 